\title{
Mutation Analysis Was Performed
}

National Cancer Institute

\section{Source}

National Cancer Institute. Mutation Analysis Was Performed. NCI Thesaurus. Code C160315.

An indication that mutation analysis was performed during the study. 